\title{
APPELLATE COURTS INSIDE AND OUT
}

\author{
Maxwell L. Stearns* \\ INSIDE APPELlate COURTS: THE IMPACT OF COURT \\ ORGANIZATION ON JUDICIAL DECISION MAKING IN THE UNITED \\ STATES COURTS OF APPEALS. By Jonathan Matthew Cohen. Ann Ar- \\ bor: University of Michigan Press. 2002. Pp. xii, 231. \$55.
}

\section{INTRODUCTION}

While the United States Supreme Court has been the object of seemingly endless scholarly commentary, ${ }^{1}$ the United States Courts of Appeals are just now coming into their own as a subject of independent academic inquiry. ${ }^{2}$ This is an important development when one considers that the vast bulk of relevant precedents governing most federal court litigation comes not from the Supreme Court, but rather from the United States Courts of Appeals. Because relatively few courts of appeals decisions are reviewed in the Supreme Court, ${ }^{3}$ with

\footnotetext{
* Professor of Law, George Mason University School of Law. B.S. 1983, University of Pennsylvania; J.D. 1987, University of Virginia. - Ed. I would like to thank Michael Abramowicz, Lloyd Cohen, Dick Ippolito, John Klick, and Vered Stearns for helpful comments and suggestions.
}

1. Providing cites for this obvious proposition would risk excluding many outstanding works that have focused upon that institution.

2. See, e.g., Tracey E. George, Developing a Positive Theory of Decisionmaking on U.S. Courts of Appeals, 58 OHIO ST. L.J. 1635 (1998). Within this literature, and for reasons that this Review makes plain, the Ninth Circuit has been a particular focus of attention. See, e.g., Arthur D. Hellman, Central Staff in Appellate Courts: The Experience of the Ninth Circuit, 68 CAL. L. Rev. 937 (1980); Stephen Wasby, Communication in the Ninth Circuit: A Concern for Collegiality, 11 U. PUGET SOUND L. REV. 73 (1987).

3 . For the twelve-month period ending September 30, 2001, the Supreme Court had 6,298 petitions for review or writ of certiorari filed plus 2,736 petitions for review or writ of certiorari pending as of October 1, 2000, for a total of 9,034. Of these, the Court granted 219, denied 5,658, and dismissed 47, leaving 3,110 petitions pending. See Petitions for Review or Writ of Certiorari to the Supreme Court Commenced, Terminated, and Pending During the 12 Month Period Ending September 30, 2001, tbl.B-2, at http://www.uscourts.gov/judbus20 01/appendices1602sep01.pdf (last visited May 21, 2003). For an alternative set of statistics for the same year, see The Supreme Court 2001 Term - The Statistics, 116 HARV. L. REV. 453, 460 (2002). Table II (B) reports 82 petitions for writ of certiorari granted out of 1,890 considered on the Supreme Court's appellate docket $(4.3 \%) ; 6$ petitions for writ of certiorari granted out of 8,023 considered for the total docket $(1.1 \%)$. Id. Table II (C), which carries over the total 88 cases "on review," further reports 70 summary dispositions (excluded from Table II (B)). Table II (B) includes cases carried to the 2001 term from the prior term, but not cases granted review in the 2001 term but carried over to the 2002 term, and further excludes cases within the Court's original jurisdiction. Id. 
rare exception, the federal circuit courts provide the functional equivalent of that Court's proverbial "last word."

It is tempting to treat the federal circuit courts as a set of miniSupreme Courts to which a massive body of available scholarship can readily be applied. But this would be a mistake. The courts of appeals are unique institutions, sandwiched between the Supreme Court and the district courts, which operate on the front lines of federal court litigation. As such, the federal appeals-courts warrant - indeed demand - independent analytical treatment. It is against this background that students of the federal judicial process must heartily welcome Jonathan Matthew Cohen's study of the United States Courts of Appeals.

In Inside Appellate Courts, Cohen, a sociologist and practicing attorney, asks a question that has received scant attention in the academic commentary on appellate judging: If we accept the dominant conception of appellate court judging as a process of atomistic contemplation, how do federal circuit court judges continue to maintain high quality opinions in the face of pervasively growing judicial dockets? Cohen advances the provocative thesis that increasing workloads have not prevented appellate judges from producing high-quality outputs, but rather, that the dominant image of appellate judging as an isolated contemplative task is conceptually flawed. A better approach, he argues, is to compare the task of appellate court judging to production within a multidivisional private firm. ${ }^{5}$ While Cohen recognizes the inherent limits of his analogy, and in particular, that unlike private firms, circuit courts lack a central coordinating authority (pp. 22, 212), he nonetheless contends that it is more fruitful to consider judges as workers in a complex organization than as autonomous actors reflecting in isolation on the legal issues presented on appeal (p. 22).

Cohen's methodology is sociological, rather than either doctrinal or economic. As such, Cohen focuses much of his discussion and analysis on questions that are of particular concern to those interested in court culture, administration, and governance: Does the proliferation of cases threaten to undermine the quality of appellate court output, assuming that it has not done so already? How do appellate courts simultaneously accommodate ever growing dockets while maintaining the proper balance between individual judicial reflection and

4. I am referring, of course, to Justice Robert Jackson's famous, nay infamous, assertion that "We are not final because we are infallible, but we are infallible only because we are final." Brown v. Allen, 344 U.S. 443, 540 (1953) (Jackson, J., concurring).

5. Pp. 30-34. Cohen's model of the sociology of the appellate courts thus draws heavily from such works as NeIL Fligstein, THE TRANSFORMATION OF CORPORATE CONTROL (1990); W. RICHARD SCOTT, ORGANIZATIONS: RATIONAL, NATURAL, AND OPEN SYSTEMS (1981); Neil Fligstein, The Spread of Multidivisional Form Among Large Firms, 50 AM. SOC. REV. 377 (1985); Richard E. Walton \& John M. Dutton, The Management of Interdepartmental Conflict: A Model and Review, 14 ADMIN. SCI. Q. 73 (1969). 
collegial deliberation? How does court size, which ranges from 6 in the First Circuit to 28 in the Ninth Circuit (p. 17), affect the ability of those courts to speak with a unified voice? Cohen focuses on these thematic questions throughout his study. Cohen also asks a series of concrete policy questions: Should the circuits be further subdivided to avoid the cumbersomeness of some of the larger circuits, especially the Ninth Circuit? ${ }^{6}$ Should Congress add a further appellate layer between the circuit courts and the Supreme Court? ${ }^{7}$ Should Congress create new appellate courts of specialized jurisdiction? (p.14). Is the Ninth Circuit experiment, authorized by federal legislation, ${ }^{8}$ of allowing mini-en banc panels of 11 within an active court of $28,{ }^{9}$ to review panel decisions of 3 , sound given the risk that a simple majority of 6 might bind that circuit to a minority position? Does the increasingly common practice in several circuits of sharing bench memoranda among the panelists threaten to compromise the judges' individual assessment of the merits? (pp. 94-95). Does the increased frequency of bypassing oral argument and of issuing summary dispositions threaten to compromise the dispensation of justice? ${ }^{10}$

It would be difficult for any student of the judicial process to deny the importance of these questions. And Cohen does not merely ask important questions. His larger task is to draw upon organizational theory to develop an original model intended to address these questions by considering the structure and organization of federal appellate courts. And yet, these questions are largely removed from the central inquiries about federal appellate courts that typically have concerned lawyers and legal scholars. The latter group has been more frequently concerned with how appellate courts transform preferences into doctrine; the nature of cases that are likely susceptible to further appellate process through en banc, mini-en banc, or Supreme Court review; and how best to evaluate appellate court opinions. ${ }^{11}$ More

6. Pp. 14, 218 (rejecting recommendation of the COMM'N ON STRUCTURAL ALTERNATIVES FOR THE FED. COURTS OF APPEALS, FINAL REPORT 47 (Dec. 18, 1998) to administer the Ninth Circuit through regional subdivisions).

7. Pp. 14, 218 (rejecting proposal advanced in Martha J. Dragich, Once a Century: Time for a Structural Overhaul of the Federal Courts, 1996 WIS. L. REV. 11 (1996)).

8. P. $182 \mathrm{n} .22$ and accompanying text (noting that Congress authorized the mini-en banc procedure, which allows fewer than the full complement of circuit court judges for circuits with more than 15 active judges, 28 U.S.C. $\S 46$ (c) (2000), and that only the Ninth Circuit uses this procedure); see also 9TH CIR. R. 35-3.

9. Circuit judges who have taken senior status are excluded from the en banc (or mini-en banc) process.

10. Cohen acknowledges that the judges he interviewed were hesitant to define such abstract concepts as justice or equity. P. 180.

11. It might surprise legal scholars reading this book that Cohen cites but a small handful of cases to support his black-letter statements concerning the standards of appellate review. See p. $47 \mathrm{nn} .20-25$.

HeinOnline -- 101 Mich. L. Rev. 1766 2002-2003 
significantly, it is not obvious that Cohen's organizational theory, drawing upon studies of the sociology of the firm, always provides the best means of assessing those policy questions that Cohen has chosen to address. While organizational theory provides a useful starting point, insights drawn from other methodologies, including economics (demonstrating how decentralized informational processes can provide more meaningful data), probability analysis (demonstrating the quality of data drawn from subsets of a larger group), and social choice (demonstrating the nature and limits of group decisionmaking), might prove more fruitful in evaluating at least some of these questions.

Cohen's study of the internal structure of appellate courts is helpful in identifying those dynamics that allow these important institutions to accommodate simultaneously the growing demand for case resolutions amid exploding dockets with the persistent command that individual judicial attention to each case is required to promote justice and equity. Cohen's focus on internal court dynamics is important because it is the tension between the dual "myths" of a burgeoning workload crisis and the isolated contemplative role of the ideal judge that has motivated the vast bulk of proposals for ambitious (sometimes radical) court reform (pp. 215-16). For students interested in how internal appellate court dynamics affect the formation and soundness of doctrine, however, it is equally important to consider external constraints that shape and discipline judges operating within collegial circuit courts. ${ }^{12}$ A comprehensive understanding of federal appellate judging therefore requires not only an understanding of the circuit courts' internal organizational structure, but also an analysis of the edifice of circuit court decisionmaking from inside and out.

This Review proceeds as follows. Part II briefly surveys Cohen's methodology and thesis. Part III draws from three complementary disciplines - economics, probability analysis, and social choice ${ }^{13}$ - to provide complementary means of assessing several of the more salient policy questions that Cohen considers and compares these methods against Cohen's sociological analysis. I conclude Cohen's model is fruitful in assessing the sociology of appellate courts. What makes his model particularly powerful is that it can be combined with other models, drawn from related disciplines, to further our understanding of appellate courts in a manner that addresses questions of concern not only to students of court administration and culture, but also to lawyers and legal scholars.

12. For an important study on the nature of lawmaking in collegial courts, see Lewis A. Kornhauser, Modeling Collegial Courts II: Legal Doctrine, 8 J.L. ECON. \& ORG. 441 (1992).

13. A proper understanding of the separation-of-powers model applied in this Subpart reveals that it is a unidimensional issue spectrum model considering the median preferences of two institutions rather than one thus fitting within a social-choice framework. 


\section{INSIDE APPELLATE COURTS}

Cohen begins his project by identifying a widely shared impression that the federal circuit courts are in crisis (pp. 5-8). That crisis, Cohen observes, grows in considerable part from the inability to reconcile two increasingly prevalent myths surrounding appeals court judging. The first myth involves the nature of appellate judging itself. The standard lore of judging begins with the observation that while district court judges, sometimes with a jury and sometimes without, try cases as individual jurists, appellate judges resolve legal issues presented on appeal in panels of three. And yet, appeals-court judges, who review questions presented on appeal based upon generally agreed upon standards of review, ${ }^{14}$ are simultaneously held to an ideal of atomistic contemplation. Each appellate judge reviews the briefs, the record on appeal, and the bench memorandum (prepared by his or her own law clerk), in an effort to decide how the appeal should best be resolved. Generally, only after reaching this initial determination does the judge then interact with the other panelists, first at oral argument, which is open to the public, and then at conference, which is not. And it is generally only at this final stage, after the judges have made their individual assessments, that the panel as a whole determines how the case is to be resolved and then assigns the initial task of producing an opinion to one of the members. ${ }^{15}$ In this traditional conception of appellate court judging, the individual effort each judge gives to the case, followed by interaction with counsel, and only then collaboration with the other panelists, are each indispensable steps in the process through which appeals courts mete out justice and equity.

The second myth is that the burgeoning caseload in the federal circuit courts have produced a workload crisis that is difficult, perhaps impossible, to reconcile with the ideal vision of the lone ranger judge. ${ }^{16}$ Thus, the number of federal appeals-court judges has risen from 132 in 1981 to 167 in 1991, where it remained stable through 2000 (p. 7 tbl.1). Meanwhile, in 1981 the courts of appeals confronted 26,362 appeals filed, 25,066 appeals terminated, and 21,548 appeals pending. Compare that to 54,697 filed, 56,512 terminated, and 40,410 pending in 2000 . So while federal circuit court size has increased by $19 \%$ in nineteen years, in the same time frame, circuit court dockets have increased by $107 \%$ (measured by cases filed), $125 \%$ (measured by cases terminated), or $61 \%$ (measured by appeals pending).

14. As Cohen correctly observes, these standards afford considerable deference to the trier of fact, whether judge or jury. Pp. 46-48.

15. Following Supreme Court practice, within the circuit courts, the chief judge or senior active judge in the majority assigns the opinion. Pp. 72-73.

16. Cohen identifies Benjamin Cardozo, Learned Hand, and Oliver Wendell Holmes as examples of heroic appellate judges who satisfied this ideal. P. 172. 
Cohen's project is to evaluate whether these and related data support various ambitious proposals for judicial reform, or instead whether the circuit courts have developed (or are in the process of developing) sufficient modest accommodations to meet the burgeoning caseload burdens while continuing to honor the proper appellate court role. To answer this question, Cohen looks closely at several actual judicial responses to the growing dockets, some of which are described below. Cohen concludes that the widely held perception that any number of radical reforms are needed to allow appeals court judges to mete out justice in the face of ever expanding dockets is misplaced and that, through a series of incremental accommodations, the courts themselves have provided mechanisms for adaptation that are superior to those most frequently advanced by various court reformers.

Throughout the book, Cohen presents two forms of data. Most significantly, Cohen presents his own data, developed through numerous interviews with judges, clerks, and secretaries on the United States Courts of Appeals for the District of Columbia, Seventh, and Ninth Circuits (and a single judge on the First Circuit). Participation was entirely voluntary and not surprisingly incomplete. ${ }^{17}$ With respect to these data, Cohen anticipates the objection of sample bias, but notes that there is no evidence to corroborate that claim (p.17 n.81). While a fair reading of the book appears to support Cohen's assertion, the manner in which these data are presented makes it difficult to know that with certainty.

Cohen presents his data in the form of quoted excepts from representative interviews. One difficulty is that Cohen does not quantify his data. While Cohen occasionally informs the reader that the speaker embraces a minority, or even a unique position, ${ }^{18}$ Cohen does not develop his interviews into a statistical database against which to assess more generally the numerical strength of various majority or minority positions. ${ }^{19}$ The result is a set of interview excerpts that provide the reader with an informative but impressionistic sense of what representative judges, clerks, and court staff think about present court operations and various proposals for judicial reform.

17. Cohen notes that within the circuits he studied, he requested interviews with all active judges and many senior judges and that participation varied from circuit to circuit. P. 16. In the Seventh Circuit, he interviewed 8 out of 11 active judges and on the Ninth Circuit, he interviewed 24 out of 39 active and senior judges. P. 16. In the D.C. Circuit, he interviewed only one-fourth of the active judges and in the First Circuit he interviewed 1 judge. Pp. 1617. Cohen maintains the secrecy of his interview subjects throughout the book, including such matters as the jurists' race or sex. P. 19 n.83.

18. Cohen notes, for example, that there was only a single dissenter within the Ninth Circuit from the practice of sharing bench memoranda. P. 95.

19. In an e-mail, Mr. Cohen explained that quantification might tend to mislead given the small sample size and the fact that during the interview process, which he conducted in person, not all questions were presented to all judges in the same form. E-mail from Jonathan Cohen to Maxwell Stearns (Feb. 2, 2003) (on file with author). 
Cohen's second set of data is taken from various published materials from the Director of the Administrative Office of the U.S. Courts. Throughout the book, Cohen presents these data, which are not original to his study, in the form of accessible tables. These data largely focus on the workload of the various circuit courts of appeals and provide a helpful backdrop against which to evaluate Cohen's interview data and policy analysis.

To support his claim that minor innovations are preferred to radical court reform, Cohen considers how the judges themselves evaluate various innovations in light of suggested alternatives. ${ }^{20}$ The most commonly advanced alternatives are subdividing large circuits, especially the Ninth Circuit; adding a further appellate layer between the circuit courts and the Supreme Court; and allowing the circuits to review panel decisions with less than the full complement of active members. Of these three approaches, only the last has been implemented. The Ninth Circuit employs a mini-en banc procedure that allows randomly drawn panels of eleven out of the full active court of twenty-eight to review panel decisions of three. ${ }^{21}$

The unique characteristics of the Ninth Circuit make it a particularly important subject in Cohen's study. Indeed Cohen frequently has more interesting things to say about that court than about the circuit courts in general. The discussion of other circuits sometimes serves as a backdrop against which to evaluate the particular problems that now confront that singularly large court, and that perhaps confronted the United States Court of Appeals for the Fifth Circuit when it had twenty-five judges prior to being subdivided into the Fifth and Eleventh Circuits (p. 183).

Several recent innovations have been widely adopted within the federal circuit courts. Among the most common responses to the conflicting demands for isolated judicial contemplation and ever increasing production burdens have been increased delegations to staff, and particularly to law clerks (p. 10); sharing of bench memoranda among the chambers of participating panelists (p. 94-101); and reducing the percentage of cases submitted for oral argument and given full

20. Cohen's approach thus raises the question as to who the intended beneficiaries of court reform are? If the intended beneficiary is the public at large, then an analysis of the likely quality of judicial outputs, rather than of judicial satisfaction with the process that gives rise to those outputs, might be a more meaningful inquiry. To answer that question, economic analysis in its various forms might prove more helpful than Cohen's interviewbased approach. By way of analogy, if one were evaluating the performance of a firm, it would appear less fruitful to ask the managers if they are pleased with the firm's internal structure and decisionmaking processes than to inquire as to how the firm has fared in the relevant market or markets in which it is engaged.

21. The selection process is not entirely random. The chief judge is always included in the mini-en banc, p. 182, thus giving a statistical edge to whichever side of the ideological spectrum the chief judge favors. 
disposition status. ${ }^{22}$ In each instance, Cohen recognizes that even these seemingly minor accommodations have not come without cost. Cohen notes that the growing professionalization within each judicial chamber - which begins to resemble a mini-law firm (pp. 27-30) - results in the judge acting more like a manager than like an individual juristscholar reflecting in isolation on how best to resolve the often complex legal issues presented on appeal. In addition, Cohen posits that the growing reliance on clerks for both bench memoranda and opinion drafts threatens to undermine judicial collegiality and the individual attention that judges are able to devote to each case. While the judges themselves generally have vast and deep experience in the law before arriving on the bench and are each subject to presidential appointment and Senate approval, law clerks are largely unregulated. Judges generally select their own clerks, ${ }^{23}$ who most often have strong academic credentials from top law schools, to work for one year prior to entering private practice or some other legal career.

As Cohen observes, the difficulty with increasing reliance on law clerks is not merely the fact of delegation by those with Article III status to those without, ${ }^{24}$ but rather the additional supervisory responsibility that can distract judges from their central task. Some have even speculated that judges can assign law clerks an outcome, thus avoiding the hard work of determining whether the law provides a convincing basis for getting there. Cohen explains:

Overreliance on law clerks may have a "big impact" on the final judicial opinion. First, ... this overdelegation enables judges to make decisions without carefully considering the logical or legal reasons for doing so. While judges traditionally have had to agonize over how a decision can be justified, now they merely can decide the case and ask their clerks to agonize over justifications. Second, delegating the initial opinion-drafting responsibility to clerks may seriously and adversely affect the opinions' clarity and style. (p. 11; internal citation omitted)

Increased judicial caseloads also threaten to undermine collegiality. Cohen identifies two aspects of collegiality that are threatened: first, the civility with which judges maintain their relationships; and second, and more importantly, the ability of judges, working together, to generate outputs that could in theory "represent the unenhanced

22. Pp. 60-63 tbl.3: Percentage of Appeals Terminated on the Merits in the U.S. Courts of Appeals After Oral Hearing by Circuit; pp. 76-79 tbl.4: Percentage of Appeals Terminated on the Merits in the U.S. Courts of Appeals Without Published Opinion.

23. At least one judge has instead assigned the task of selecting clerks to a committee of law professors. P. 90.

24. And of course this problem is not unique. It has been noted that elected members of Congress routinely delegate major functions to staff, and often read only committee reports, drafted largely by staff members, rather than the actual bills upon which they vote. For a general discussion, see Daniel Farber \& Philip B. Frickey, Legislative Intent and Public Choice, 74 VA. L. REV. 423, 439 (1988). 
effort of a single person," and that are the product of meaningful "collaboration and deliberation." 25 In addition, an increase in court size itself threatens to undermine judicial reflection and collegiality. ${ }^{26}$ This threat appears especially acute in the Ninth Circuit, which has twenty-eight judges, and which in recent years has witnessed the Supreme Court's lowest approval rating. ${ }^{27}$

As have multidivisional private firms, the circuit courts have developed several methods of accommodating a changed working environment. In addition to reliance on clerks, Cohen observes that it is an increasingly prevalent practice among the circuit courts for the members of a three-judge panel to share a single bench memorandum (p. 94). This allows each chamber to prepare memoranda in roughly one third of the cases assigned to the panel, rather than having one clerk in each chamber independently brief each case.

And yet, Cohen observes that the mere fact of circulation among chambers changes the process of drafting the bench memorandum. At least one Ninth Circuit judge noted that the circulated memorandum requires more work because it represents the chambers (p. 95). As a result, the judge in the originating chambers is more likely to have a hand in influencing the reasoning expressed in the memorandum ( $p$. 107). In other chambers, the judge allows the memorandum to circulate entirely as the clerk's work product with no judicial imprimatur (p. 108). Whether or not the judge reads the memo prior to distribution, the fact of external circulation encourages greater detail than might be appropriate if a clerk, aware of his or her own judge's jurisprudential predilections, were drafting solely for internal use. Some judges have complained, for example, that circulated memoranda are simply less useful to them than those prepared solely for use within the chamber by their own clerks and therefore have law clerks produce comment memoranda that respond to the circulated memoranda (pp. 101-03).

Circulated memoranda also affect the incentives of other judges on the panel. Some judges tend to back load case preparations when their clerks are not responsible for preparing the circulated bench memorandum (p. 107). This tendency not only delays preparation, but might also promote reliance on the circulated bench memorandum, at least until shortly prior to oral argument.

25. P. 12 (quoting Lewis Kornhauser \& Lawrence Sager, The One and the Many: Adjudication in Collegial Courts, 81 CAL. L. REv. 1, 3, 5 (1993) (internal quotation marks omitted)).

26. Cohen distinguishes geographic from numerical dispersion; the latter threatens to undermine collegiality more so than the former. Pp. 152-66.

27. For a comprehensive treatment of the Ninth Circuit approval rating, see Richard A. Posner, Is the Ninth Circuit Too Large? A Statistical Study of Judicial Quality, 29 J. LEGAL STUD. 711 (2000). 
In addition, many circuits have increased their reliance upon visiting judges (pp. 194-95 tbl.7). This helps to reduce the workload on active circuit members, but again does not do so without cost. As Cohen observes, from the perspective of the sitting circuit court panelists, not all visitors are created equal. Those visiting from other circuit courts of appeal are treated less skeptically than those visiting from the district courts. This is partly because members of other circuits have like experience and prestige (p. 193), and partly because those visiting from district courts often find the work of the circuit court to be a distraction from their main task of deciding cases at the trial level (p. 197). Some circuit court judges also expressed concern that district court judges tend to view the case from the trial court perspective, rather than from the perspective of an appeals court evaluating identified claims of error (p. 198). And even visitors from other circuits can pose problems. Visiting circuit judges sometimes believe that their own circuit has adopted a superior approach to a particular question of law, and seek to foist their view on the circuits they are visiting ( $p$. 196). Cohen's anecdotal evidence suggests that this attitude tends to create resentment among the host judges who generally prefer to resolve such issues on their own (p. 196).

Almost all of the circuit courts have reduced the percentage of cases given oral argument and full disposition treatment, including published opinions (pp. 60-63 tbl.3; pp.76-79 tbl.4). While none of the quoted judges claim to give short shrift to cases that are decided on the briefs, the general rule preventing citation of unpublished opinions (pp. 73,81 ) clearly affords judges more leeway by reducing the need for precision in setting forth the governing rationale. ${ }^{28}$ Again, this practical accommodation does not come without cost. Cohen notes that commentators have criticized the reduced percentage of published opinions on the ground that it poses a threat to the legitimacy of the judicial process (p. 74).

Of all the accommodations that Cohen discusses, perhaps the most ambitious is the Ninth Circuit mini-en banc regime. Authorized by Congress, this regime allows the court to empower eleven judges, rather than the full complement of twenty-eight active judges, to review panel decisions of three. And while the circuit could, in theory, vote for a full-en banc if dissatisfied with the rulings of a mini-en banc panel, Cohen reports that each of the three post mini-en banc requests for such review has failed (p. 189). Some members have concluded that this fact alone reveals the efficacy of the mini-en banc regime ( $\mathrm{p}$. 189). And perhaps from the perspective of the participating judges,

28. Thus, Cohen observes, "Because the judges put far less effort into writing and editing their unpublished dispositions, their reasoning often is less tightly written, and phrases sometimes indicate broader statements about the law than the writing judge or other panel members would allow in a published, citable opinion." P. 79. 
that is correct. What the sociological data cannot identify, however, are the precise tradeoffs in expediency associated with the mini-en banc versus the resulting loss in meaningful representation of the full-en banc court. Cohen ultimately recognizes this as a statistical problem (p. 187), but he nonetheless relies upon quoted excerpts from judges regarding their overall satisfaction with the mini-en banc regime, rather than analyzing the problem in terms of probabilities. ${ }^{29}$

Just as private firms alter their internal structure to improve their functioning in a changing external environment, Cohen argues that these generally modest accommodations (holding aside for now the mini-en banc) reveal the flexibility and adaptation of the various circuit courts of appeals. And as with private firms, each of these developments can be ascribed to a changed condition that required an institutional response by those who are most concerned with meeting those changed circumstances while also ensuring, as much as feasible, consistent quality of output. Cohen's broadest claim is that each of these changes, which admittedly reduce the level of attention that individual judges devote to each case, is acceptable because the task of appeals-court judging, as in a private firm, is ultimately one of joint production.

In the next Part, I will consider three other approaches to appellate court decisionmaking, which individually and in combination will help to assess the strengths and limitations of Cohen's organizational thesis. Specifically, these three approaches will help to evaluate Cohen's major claim that the observed innovations, each intended to accommodate growing judicial dockets in the circuit courts of appeals, are preferred to seemingly more bold proposals for circuit court reform. I will focus on three of the most significant of these innovations: shared bench memoranda; the increased use of summary dispositions; and the Ninth Circuit mini-en banc procedure.

29. At one point, Cohen states: "One response to the problem of the mini-en banc is that, once it is agreed that any number less than a full court is acceptable, deciding how large the panel should be is merely a matter of statistics." P. 187. But then he goes on to paraphrase a Ninth Circuit judge who

stated that the court had done a study that concluded that statistics suggest that eleven judges closely represent the views of the whole court and that to increase the probability that a panel with fewer than the full complement would represent the whole, the panel would need to have fifteen judges.

P. 188. While Cohen never cites this study, he goes on to state "[t]hat judge suggested that the small marginal benefit of adding more judges would not be worth the added inherent difficulties." Id.. 


\section{INFORMATION, REPRESENTATION, AND COLLECTIVE CHOICE}

\section{A. The Economics of Generating Information}

Throughout his study, Cohen evaluates the soundness of several innovations according to the satisfaction of the judges, who he assumes to be most directly affected, as reflected in the interviews. In evaluating many aspects of judicial culture, including several that are discussed in his book, this approach appears sound. Thus, for example, it would be difficult to assess satisfaction with the physical structure of various judicial chamber configurations (pp. 118-21), the appropriate tasks within chambers that law clerks perform (pp. 118-21), or the best methods of judicial communication concerning pending cases (pp. 15460 ), without asking the judges themselves. No other obvious benchmarks besides the satisfaction of jurists emerge. But Cohen does not ask the question whether his methodology is optimally suited to all of his questions about the nature of appeals court judging. And for some of the questions, I would suggest, the interview approach yields data that are simply less fruitful than data or insights that emerge from other, complementary, methodologies.

Let us begin with shared memoranda. As explained in the prior Part, Cohen presents numerous and lengthy interview excerpts concerning judicial satisfaction with the recent trend in several circuits of assigning one chamber per panel to prepare a single memorandum in each case, and then circulating that memorandum among the chambers of the panelists. While the general support for the practice is not unqualified, and while some judges have their clerks produce supplemental memoranda that respond to the somewhat generic and less targeted circulated bench memoranda, Cohen's data suggest considerable support among chambers for this regime.

And yet, a simple economic model helps to identify potential costs that might not be well captured in Cohen's data. In the course of presenting his interview excerpts, Cohen identifies several important propositions related to sharing bench memoranda among chambers. Many jurists point out the obvious, namely that the practice reduces work by about two-thirds, at least if you assume that the practice does not change the amount of work going into each memorandum (pp. 94$95)$. Others point out the flaw in this very assumption, noting that the fact of circulating the memoranda requires greater judicial attention by the originating chambers than was the case when such memoranda were used solely within the chambers (p. 96). And several jurists noted that the resulting memoranda tended to be less useful because they were pitched to a broader audience and because they therefore had a substantial tendency toward overinclusiveness (p. 96). At least one judge, clearly expressing a minority position among those for whom interview excerpts were presented, claimed that the traditional regime 
of preparation within each chamber was superior because redundancy itself is an affirmative good that has been deliberately built into the system of appellate judging (p. 100).

The difficulty, of course, is in evaluating these competing claims. Even if we identify substantial costs associated with the shared memorandum practice, there might be no "right" answer in evaluating whether the benefits of reduced work within each chamber outweigh the costs. But it would certainly be helpful in undertaking a policy analysis of that sort to identify just what the relevant tradeoffs are. And in this instance, an economic model might well prove more fruitful than asking the participating judges who are particularly sensitive to workload.

The analysis rests only upon the assumption that the actors in question are rational, taking their preferences as given. While that might be a contestable proposition, it builds upon Cohen's analogy of appellate judging to production in a multidivisional private firm. Of course, economists are unlikely to evaluate firm performance by asking managers how they think they are doing. Rather, they are likely to assess performance according to objective market indicators. And since even that task can be exceedingly difficult, economists often employ simple models designed to predict how certain changes in firm behavior or in the external environment in which the firm is operating are likely to affect market performance.

In this instance, we have a single change in the behavior of the court/firm, namely a reduction in the number of data generated prior to the critical decisionmaking junctures - oral argument and conference - that precede the drafting and issuance of the opinion. Rather than having three independently generated bench memoranda, one to each judge, as a principal information source prior to oral argument, we now have a single memorandum shared among the chambers. Without suggesting that federal circuit judges, or even their clerks, are unable to evaluate quality and to reject shoddy work product, we can see that in private markets, the baseline assumption is that multiple independently generated data points are more effective than a single datum in producing and conveying meaningful information concerning such matters as the value of commodities, the accuracy of news accounts, or the soundness of positions advanced on ballots or in campaigns. $^{30}$

Rather than having a central organizing authority try to surmise the scarcity of, and demand for, resources, open markets allow countless individual actors, operating in the absence of any central coordinating authority, to transact at prices that buyers and sellers individu-

30. Elementary courses in economics generally begin with the determinants of price in large part because they are conceptually easy to present. But the principles apply as well to any number of data. 
ally - and with mutual assent - deem appropriate to the goods or services in question. One major benefit of generating information as to value in this decentralized and uncoordinated manner is that countless subjective valuation measures - reflected in the individual transactions - produce an objective valuation that can be tested in the marketplace. ${ }^{31}$ Thus, if an individual seller subjectively valued a commodity more highly than the prevailing market price, she could try, generally without success, to secure that higher price in the market. Holding all else constant, price theory predicts that such efforts are destined to fail. Conversely, another seller who values the commodity less highly than the prevailing market price could enter her goods in the market at a discount. Holding all else constant, the demand for her goods would then be infinite. The seller could then altruistically continue to sell at the reduced price until she runs out, or she could recognize her ability to raise the price to that prevailing in the market, and sell as much as is profitable at that price.

Thus, if we assume complete competition and indistinguishable goods, the only relevant question, and the one that the market is wellsuited to answer, is valuation, or price. And price is best provided in a decentralized market in which multiple independently derived data points allow us to confirm or deny the validity of any one person's subjective valuation as an alternative proxy for value. Of course, judges do not produce a simple price datum; instead, they produce opinions that resolve disputes and establish precedents. And it is not always true that private actors making individual decisions produce ideal information. Recent studies in experimental economics have shown for example that decentralized decisionmaking can sometimes produce cascade effects. ${ }^{32}$ In the absence of information, and presented with some datum, consumers will often assume the available datum to be true and treat it as such. This can advantage an early posi-

31. As is standard, the discussion assumes the absence of negative externalities.

32. For a general discussion, see Timur Kuran, Private Truths, Public Lies: The

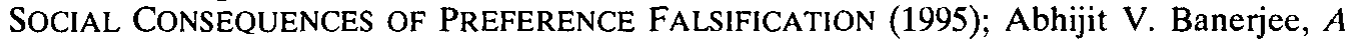
Simple Model of Herd Behavior, 107 Q.J. ECON. 797 (1992); Sushil Bikchandani et al., Learning from the Behavior of Others: Conformity, Fads, and Informational Cascades, J. ECON. PERSP., Summer 1998, at 151; and Timur Kuran \& Cass R. Sunstein, Availability Cascades and Risk Regulation, 51 STAN. L. REV. 683 (1999). One author has recently described the phenomenon as follows:

Social groups move rapidly towards a set of beliefs that may be unsupported by evidence, in a process that is like a chain reaction or cascade of disinformation, and which is self-reinforcing. This effect is generated by a number of factors, including the difficulty of becoming fully apprised of all evidence, the difficulty of assessing this evidence, the emphasis placed upon recent information due to cognitive processing shortcuts such as the "availability heuristic," deference to socially-dominant influential information arbiters, and concerns about reputation and social standing in the event of disagreement.

Dan Hunter, Philippic.com, 90 CAL. L. REV. 611, 621-22 (2002) (reviewing CASS R. SUNSTEIN, REPUBLIC.COM (2001) (internal citations omitted)). 
tion relative to its merit. ${ }^{33}$ Cascade analysis has thus been used to explain, for example, such phenomena as reactions to published accounts of global warming and dubious claims about the cause of the spread of AIDS in Africa. ${ }^{34}$ But notice that the predicate to information cascades is a dearth of meaningful and independently generated information, and the presentation of some source of information, whatever its quality, to fill the void. The tendency is to assume available information to have merit until it is disproved, often through the discovery of superior and falsifying alternative information..$^{35}$

I do not intend to imply that the shared-bench-memorandum regime ensures an information cascade. As stated previously, Article III judges are generally extremely well-educated and critical thinkers. But the shared bench memorandum regime changes the flow of information in a significant way. In assessing the impact of this change, it will be helpful to consider an important appeals court norm that Cohen also identifies. In his discussion of court culture, Cohen explains that judges decline to discuss the merits of a case prior to oral argument (pp. 131-33). A simple economic analysis reveals that the shared memorandum regime provides a mechanism through which ambitious judges can subvert that important court norm. In so doing, it provides the other judges with information about the preferences of one panelist, which would take agreement of both remaining panelists to defeat.

The analysis begins with the assumption that within any given three-judge panel, at least one judge is likely acquiescent, and at least one judge is likely dominating. By acquiescent, I do not intend to imply intellectual laziness or sloppiness. It is quite possible, for example, that a visiting judge, or a judge who has not been on the court for a long time, might tend to defer to those whom he or she believes have a greater institutional understanding, or that he or she prefers to have the court speak with a unified voice even if occasionally that requires subordinating his or her own views. The likelihood of an acquiescent judge is perhaps enhanced as a result of the recent trend toward increased reliance upon visiting judges, but the analysis that follows is certainly not dependent upon that development. A dominant judge, on the other hand, is one who if afforded the opportunity, will attempt

33. See Kuran \& Sunstein, supra note 32, at 685-86 ("An information cascade occurs when people with incomplete information on a particular matter base their own beliefs on the apparent beliefs of others.").

34. See Hunter, supra note 32, at 621-22; Kuran \& Sunstein, supra note 32, at 723; Jeffrey J. Rachlinski, The Psychology of Global Climate Change, 2000 U. ILL. L. REV. 299, 312.

35. I do not mean to suggest that there is a binary choice between meaningful decentralized, and misleading coordinated, information. In most instances, information sources fall between these two extreme endpoints, and for some inquiries, those that are scientific and falsifiable, the number of persons who embrace a position is a meaningless indicator of quality. 
to persuade other judges to adopt her viewpoint in an effort to secure a desired case resolution and precedent. While in any given panel it is possible to have all dominant or all acquiescent judges, I will assume for the analysis to follow that each panel has at least one of each, and then consider the implications of the shared memorandum regime.

Assume an acquiescent judge receives a memorandum from the submitting chamber and that the remaining chamber does not respond. Silence can either signal that the third judge is also acquiescent or that he or she agrees on the merits. In either case, the known acquiescent judge is likely to assume that two out of three judges are satisfied with the analysis in that memorandum. This increases the probability that the judge in question will enter oral argument inclined toward that view of the case. Now assume instead that after the memorandum circulates, the remaining chamber responds negatively, for example by submitting a memorandum objecting to the analysis contained in the bench memorandum in some important respect. The submitting chamber might respond negatively, in which case the acquiescent judge will inevitably confront two competing views expressed by two dominant judges. Alternatively, the submitting chamber might not respond or might respond favorably. In that case, the acquiescent judge is likely to take the signal as favoring the views of the responding judge. If we set aside the case of two dominating judges expressing disagreement, the other two cases - two judges agreeing with the memorandum and two judges disagreeing with the memorandum - produce a signal that the third, acquiescent judge is likely to find important in entering the next phase of the appellate process.

Now contrast the traditional regime in which each chamber prepares its own memorandum without sharing. In this regime, the judges enter oral argument without any written submission revealing how another panelist, or her clerk, views the case. Assume a clerk within each chamber submits a memorandum to his or her judge, and that the memoranda are regarded as sound by the judges receiving them. If the memoranda agree, then barring some unanticipated response at oral argument, the judges are likely to prefer the outcome that is consistent with the memoranda. If the memoranda disagree, then the judges will enter oral argument with at least two competing views of the case. This is likely to generate a more active and engaging oral argument, and also to encourage the judges to find some basis for reconciling the differing approaches. It is entirely possible that one of the judges will dominate the panel, but at a minimum, the judge whose initial inclination was to view the case differently will have to report back to the clerk that she has changed her view of the case. This is likely a minor 
cost, but it is a cost nonetheless, and one that is reduced - if not eliminated - in the shared-memorandum regime. ${ }^{36}$

The analysis reveals that the shared-memorandum practice imposes a cost of reducing the flow of independently generated information, in favor of coordinated and shared information. The regime saves the cost to clerks of preparing memoranda in each case, and in a regime with growing dockets, judges are acutely aware of this benefit.

A similar analysis confronts the increased tendency toward memorandum dispositions without oral argument. Both features of this practice - bypassing oral argument and declining to publish the resulting opinions - reduce the information associated with applying precedents to new fact patterns that arise in actual cases. Certainly the judges themselves are well suited to identifying which cases are important in the evolution of doctrine and which are instead straightforward applications of existing principles of law. ${ }^{37}$ But multiple applications even of well-understood doctrine can expose important nuances. And at a minimum, more published opinions provide litigants with more information concerning relevant rules of law. Anecdotal evidence suggests that lawyers will invest in assembling data concerning unpublished legal materials. ${ }^{38}$

These elementary economic intuitions are certainly not sufficient to answer the question whether the costs of shared memoranda and memorandum dispositions outweigh the benefits, but they do demonstrate a real cost that is not well captured in the data Cohen has assembled, and they further reveal how those data are likely biased against weighing what might be a significant cost. In the next Section, I will demonstrate how probability analysis can edify Cohen's discussion of another, and more ambitious, innovation: the mini-en banc.

\section{B. A Probability Analysis of the Mini-En Banc Procedure}

With congressional authorization, the Ninth Circuit has adopted a mini-en banc procedure that allows eleven judges out of twenty-eight to reconsider a three-judge panel decision. Cohen spends considerable time in the book on this particular innovation (pp. 162-63, 182-91, 20809, 216-19), which appears to be the most ambitious of those that he discusses, and perhaps the most ambitious that the federal circuit courts have yet adopted to deal with the workload crisis. It is easy to

36. Cohen notes that one judge stated that "by not communicating his initial views of a case to his brethren, he has not committed himself to a view, and he can more readily change his mind without the embarrassment of admitting to his colleagues that his initial view was incorrect." P. 132.

37. And notice that judges sometimes publish "reminder" opinions that involve easy factual applications when such opinions have not been issued for some time. P. 75.

38. See, e.g., Leandra Lederman, Tax Court S Cases: Does the 'S' Stand for Secret?, 79 TAX NOTES 257 n.5 (1998). 
identify the potential flaw with this regime. A minority of the full court, consisting of six judges out of eleven on the mini-en banc, can bind the circuit to a position that, in theory, as many as twenty-two judges reject. If we assume that the traditional procedure of allowing the entire court en banc to review the decisions of individual panels is designed to ensure that either intracircuit splits or egregious examples of outlier rulings are corrected consistently with the overall preferences of the circuit,$^{39}$ this suggests that at least part of that formulation is violated with mini-en banc review. Setting aside associated problems of intransitive voting preferences ${ }^{40}$ as a general matter, it is practically impossible for an en banc court to engraft a minority position onto the law. While a mini-en banc can cure intracircuit conflict, as several judges have noted, the regime also threatens to empower minorities on the court to express the rule of law (p. 186). Nonetheless, as with the other innovations described throughout the book, the Ninth Circuit judges appear generally satisfied with the regime. The difficulty is in identifying practical solutions to the problems that have been identified. Cohen recognizes the problem as statistical (pp. 18788 ), and at one point, quotes a judge who claims that a Ninth Circuit study established the need to raise participation from eleven to fifteen out of twenty-eight judges to solve the representation problem (p. 188). It turns out that the solution is not so easy, and that a fairly simple probability analysis reveals why.

In this Part, I will employ a hypergeometric distribution to demonstrate the probability that a given mini-en banc panel will achieve a result contrary to that which would have been achieved with the full Ninth Circuit sitting en banc. ${ }^{41}$ The probability analysis will not be complete. In particular, I will not recount every possible combination.

39. This formulation admittedly begs an important normative question, albeit one that Cohen declines to address, namely: What is the purpose of en banc review? Obvious candidates include increasing the likelihood that circuit court decisions are "correct" based upon some agreed-upon normative criterion; increasing the likelihood that circuit court rulings anticipate probable Supreme Court rulings; and reducing the incidence of outlier panel rulings and intracircuit conflict. Michael Abramowicz has challenged these formulations in a recent article and proposed instead that en banc decisions should mirror the overall preferences of all federal circuit judges, a goal that is promoted by increased reliance upon visitors. Michael Abramowicz, En Banc Revisited, 100 COLUM. L. REV. 1600 (2000). My own view is that en banc review should instead reflect the jurisprudential views of the active members of the deciding circuit court. This approach increases the probability that when splits of authority arise among the circuits (bearing in mind that panel rulings are themselves disciplined in part by anticipated en banc rehearings), they are genuine and not based upon such happenstance factors as a random draw, which would be the case if visitors were allowed to vote on en banc panels, and which is the case with the mini-en banc review.

40. See Maxwell L. Stearns, Constitutional Process: A Social Choice ANALYSIS OF SUPREME COURT DECISION MAKING 106-11 (2000) (illustrating multidimensionality and asymmetry in Supreme Court opinions).

41. I am particularly indebted to Lloyd Cohen, Dick Ippolito, and John Klick for helping to formulate the probability analysis set out in this Subpart. 
Rather, I will highlight some particularly problematic cases in which the mini-en banc procedure threatens to codify a minority position, and then evaluate the nature of the changes required to avoid the problem. In the end, I will suggest a possible improvement to the minien banc procedure, one that admittedly imposes some significant administrative costs. Whether the problems with the mini-en banc as presently formulated warrant a shift to such an alternative regime, or the adoption of some other solution, ${ }^{42}$ is of course a policy question that no model can answer. But the analysis is sufficient to establish the limits of the interview-based methodology, in contrast with a probability analysis, in identifying the tradeoffs relevant to such a policy analysis.

I will present the findings in two ways. Table 1 shows the probability that an odd numbered mini-en banc of increasing size (depicted in the left horizontal column and ranging from eleven to twenty-seven judges) will achieve a contrary resolution to that achieved in an en banc court of twenty-eight for various levels of consensus within the larger court (depicted along the top numbered row). ${ }^{43}$ The totals are listed across each row for the mini-en banc panel of each designated size and matched to each level of consensus that produces a given outcome on the full court. It is important to emphasize that embedded in the analysis is a normative assumption that the purpose of the mini-en banc is to mirror the outcome that would likely be reached if the full court decided the case en banc. ${ }^{44}$ If we accept that premise, then the data reveal that in close cases (defined here as 15-13 voting "yes" in the full-en banc), the eleven-judge mini-en banc threatens to undermine the preferences of the en banc court as much as $38 \%$ of the time. This is of course problematic. But it is all the more disturbing to realize that in such a close case, an en banc of thirteen would likely achieve the wrong result $36 \%$ of the time, an en banc of fifteen would likely achieve the wrong result $34 \%$ of the time, an en banc of seventeen would likely achieve the wrong result $32 \%$ of the time, an en banc of nineteen would likely achieve the wrong result $29 \%$ of the time, an en banc of twenty-one would likely achieve the wrong result $25 \%$ of the time, an en banc of twenty-three would likely achieve the wrong result $21 \%$ of the time, and an en banc of twenty-five would

42. Obvious candidates include dividing the Circuit; employing subdivisions within the Ninth Circuit and leaving the en banc court as a mini-Supreme Court that resolves splits among the subdivisions; and rejecting the mini-en banc regime in favor of a full-en banc, perhaps limited to ruling solely on the pleadings.

43. Because a "no" outcome could arise in the mini-en banc under any combination in which a majority achieves that outcome (for example in an eleven-judge panel, it could occur if a majority elects "no" based upon votes of 6-5, 7-4, 8-3, 9-2, 10-1, and 11-0), these possible no votes have been tallied to reveal the probability of the mini-en banc court achieving the "wrong" answer.

44. See supra note 39. 
likely achieve the wrong result $14 \%$ of the time. Rather than solving the problem, in a close case for a twenty-eight member court a move from a mini-en banc of eleven to a mini-en banc of fifteen would merely reduce the likelihood of an incorrect result from $38 \%$ to $34 \% .{ }^{45}$

A 15-13 split for the court as a whole, of course, presents the worst-case scenario for the likelihood of a wrong outcome. The probability that the eleven-judge panel achieves a result contrary to the full court diminishes as the consensus level within the full-en banc court rises. Table 1 again provides the relevant data. The data reveal that the mini-en banc court is $38 \%$ likely to get the wrong result if the full court is split $15-13 ; 27 \%$ likely to get the wrong result if the full court is split $16-12 ; 18 \%$ likely to get the wrong result if the full court is split $17-11 ; 10 \%$ likely to get the wrong result if the full court is split $18-10$; $5 \%$ likely to get the wrong result if the full court is split 19-9; and $2 \%$ likely to get the wrong result if the full court is split 20-8. Beyond that level of consensus, the chances of error are minuscule. When twothirds or more of the judges want to vote "yes," there is no more than a $5 \%$ chance that an eleven-judge mini-en banc panel will get the "wrong" result. Otherwise, the probability of a contrary result greatly increases as demonstrated above.

One could reject the significance of these data by assuming a highlevel consensus in the general run of cases. Whether or not that is correct, the answer is not entirely satisfying. It is quite likely that closely divided cases are more significant, at least in terms of salience, and therefore that the contrary resolution by a mini-en banc matters most just when the mini-en banc is most likely to get the wrong result.

Before leaving the probability analysis, it is helpful to recognize that it is not possible to know the consensus level within the full-en banc court, at least absent review at that level. It is possible, however, to know the outcome within the mini-en banc, and then to assess the probability that the outcome for that consensus level is contrary to that for the entire en banc court for any given level of consensus. Table 2 shows that in cases that would produce a 15-13 margin for the entire court, an en banc decision of $6-5$ is $24 \%$ likely to be incorrect; an en banc decision of $7-4$ is $11 \%$ likely to be incorrect, an en banc decision of $8-3$ decision is $2.7 \%$ likely to be incorrect, and beyond that the likelihood of an incorrect decision is extremely low. ${ }^{46}$ One possibility short of eliminating the mini-en banc for increasing its probable accuracy is to posit an acceptable benchmark of consensus within the

45. Readers can use the same table to determine the effect of increasing the size of the mini-en banc panel for higher levels of consensus within the full twenty-eight judge court by selecting a consensus level from the top-numbered row and then reading down for each additional increment in size of the odd-numbered mini-en banc panel.

46. Using the same technique described supra note 45 , readers can use this table to assess probabilities of an incorrect result for various consensus levels within the mini-en banc of eleven for higher consensus levels within the full court. 
mini-en banc panel itself and to require an increase in the sample size if the benchmark is not met. ${ }^{47}$ If, for example, we accept a $5 \%$ probability of error, but not a larger one, then one could envision a regime that works as follows. If a mini-en banc ruling arises with fewer than eight in the majority, the court can either reinstate the three-judge panel decision or vote again for a full-en banc. ${ }^{48}$ In either case, the mini-en banc will not be controlling. I am not advocating this regime, but rather, am suggesting it as one intermediate solution to the problem of representation that confronts the mini-en banc.

It is important to emphasize that nothing in this analysis answers what is perhaps the most critical question: Are the benefits of the mini-en banc sufficient to outweigh the costs? But the analysis does suggest that asking the judges their views might not provide a very compelling basis for assuming the answer to be yes. The mini-en banc procedure is time saving and helps to preserve the Ninth Circuit as a single court. Most judges seem to agree that absent this procedure, en banc proceedings would be a near impossibility on the present 28 judge court. ${ }^{49}$ If so, then this might raise anew proposals - admittedly more radical - to either formally split the Ninth Circuit, or to treat that court as managing two or more internal mini circuits, each with its own body of precedent. But in one sense, the solution to split the circuit is less radical than the mini-en banc. Circuits have been split in the past, and other than the cumbersomeness of adding a fourteenth federal circuit, ${ }^{50}$ and perhaps one that embraces a single state, ${ }^{51}$ this would

47. For descriptions and applications of a Simon two-stage design, used for testing the efficacy of drugs, see Richard Simon, How Large Should a Phase II Trial of a New Drug Be?, 71 CANCER TREatMent ReP. 1079 (1987); Richard Simon, Optimal Two-Stage Designs for Phase II Clinical Trials, 10 CONTROL CliniCAL TRIALS 1 (1989). Simon's technique involves taking a small sample size - fourteen in the studies under review - and then basing the need for a larger sample size on the response. If no patients experience a desired response, the study ends at stage I. If instead some patients experience a desired response (generally no more than one to three will do so) then the test proceeds to stage II, which increases the sample size. In the two-stage trial, if at least one patient obtains the desired result out of fourteen, then there is a chance of $20 \%$ efficacy, which can be confirmed or denied with a larger sampling. A similar principle can be applied to the mini-en banc regime. If the favorable response within the smaller eleven-judge sample is too low, for example anything less than an 8-3 outcome, then the probable accuracy of the result can be tested by increasing the sample size to the full twenty-eight-judge en banc court.

48. While it is true that a random three-judge panel is less likely as a matter of probabilities to reflect the full twenty-eight-judge court's preferences, this is a general feature of circuit court practice and is not one that pretends to reflect the preferences of the full court sitting en banc.

49. This might be less of a problem if en banc proceedings were based entirely upon the pleadings and thus without oral argument, as my colleague Michael Abramowicz has suggested. Abramowicz, supra note 39. But there might well be resistance to denying oral argument in the small class of salient cases that warrant full-court review.

50. Presently we have eleven numbered circuits, plus the District of Columbia and Federal Circuits.

51. One particular anomaly that confronts the Ninth Circuit is that dividing the court

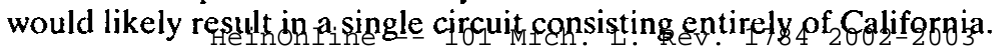


entail no major alteration in the present practices in the circuit courts. The same cannot be said for the mini-en banc, which represents a substantial departure from the practice in other circuits. Likewise, the intermediate step of treating the Ninth Circuit as a mini-Supreme Court above two or more internal subcircuits deviates from the standard practice of the other circuits. At a minimum, the analysis suggests the need for further study, and I would argue, for additional disciplinary approaches in the course of that study.

\section{The Economics of Generating Doctrine}

Most students of courts are interested in the nature and determinants of judicial doctrine. For these readers, Cohen's project is particularly interesting because it reveals how the processes of judicial crafting of doctrine can be affected by growing dockets and by the increased size of existing courts. The mini-en banc, the decline in full disposition opinions, and the increased use of visiting judges, all have the potential to change the most important aspect of judging, namely the opinions that judges produce and the rule of law that those opinions announce. While this is not a question that Cohen takes up directly, he suggests throughout his book that collegiality is an important factor in judging. And certainly collegiality is not important for its own sake, but rather it is important for its impact on the processes and end product - judicial opinions - of appellate court decisionmaking. In this Section, I offer a preliminary model, drawn from the separationof-powers and social-choice literature, that will help to consider just how these developments might affect the ultimate transformation of judicial preferences into legal doctrine.

The separation-of-powers model predicts probable Supreme Court rulings according to whether Congress is likely to change the result by enacting a contrary statute. ${ }^{52}$ The model assumes that both the Court and Congress can be cast along a single-normative-issue dimension, such that for each branch, one can identify something like a median member, whose preferences govern. ${ }^{53}$ When the Court anticipates that

52. For useful presentations of this model, see William N. Eskridge, Jr. \& John Ferejohn, The Article I, Section 7 Game, 80 GEO. L.J. 523 (1992), and William N. Eskridge, Jr. \& John Ferejohn, Virtual Logrolling: How the Court, Congress, and the States Multiply Rights, 68 S. CAL. L. REV. 1545 (1995).

53. The purpose here is not to defend or challenge these obviously strong assumptions, but rather to consider whether the framework of the model is helpful in evaluating judicial lawmaking in the circuit courts. As with all economic models, the assumptions driving this one are contestable. It is not at all obvious that Congress is best characterized as an institution with preferences that rest along a single dimension. See MAXWELL L. STEARNS, PUBLIC CHOICE AND PUBLIC LAW 370-71 (1997). And in deciding individual cases and groups of cases, it is demonstrable that the Supreme Court frequently possesses preferences that rest along multiple dimensions as well. See STEARNS, supra note 40, at 106-11 (demonstrating with individual cases); 170-98 (demonstrating with groups of cases over time). And even if

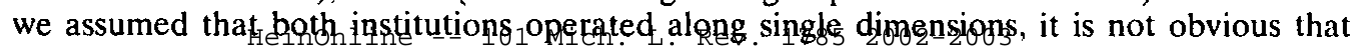


a preferred ruling, consistent with the preferences of its median member, falls outside of the median range for Congress, its options are to cast the ruling in constitutional terms, thus preventing an overruling, ${ }^{54}$ or to move the decision closer to the legislative median to "insulate" the judicial ruling. So viewed, the Court's members are not merely internally strategic, ${ }^{55}$ but are simultaneously strategic respecting as a coordinate branch.

Ironically, the assumptions required for the separation-of-powers model are weaker and thus more plausible when the model is extended to apply to circuit courts because in this context only one institution is involved. It is entirely plausible, although not inevitable, to assume that if the court views the case as resting along a single-issue dimension, subgroups within that court will also view the case as resting along the same analytical dimension. We can therefore think of the Ninth Circuit as having three potential levels of participation, a full-en banc of twenty-eight judges, a mini-en banc of eleven of twenty-eight, and a panel of three of twenty-eight. As with the Supreme Court, it is certainly unlikely that the Ninth Circuit, or any other appeals court, systematically possesses preferences that can be cast along a single normative issue dimension. ${ }^{56}$ But for the analysis to follow, let us assume that this is the case, or perhaps more accurately, let us assume that the following analysis applies when this is true.

We can now intuit a game in which members of a three-judge panel (in the absence of a mini-en banc procedure) try to contemplate not only their own dominant position, but also the relationship of that position to the expected median of the entire en banc court. ${ }^{57}$ Along whichever substantive issue dimension on which the case rests, the panelists could be "strategic" not only respecting each other, but also respecting the larger court. Specifically, if the preferences of the most liberal member of a conservative panel or of the most conservative member of a liberal panel are a significant distance from the prefer-

they operate simultaneously on the same dimension. Thankfully, it is not necessary to defend the separation of powers model here. It is only necessary to explain the basic intuition.

54. Within the framework of social choice, this involves casting the decision along a separate analytical dimension.

55. For relevant discussions of strategic voting within appeals courts, see FORREST Maltzman et al., CRafting LaW on the Supreme Court (2000), and Evan H. Caminker, Sincere and Strategic Voting Norms on Multimember Courts, $97 \mathrm{MICH}$. L. REV. 2297 (1999).

56. See STEARNS, supra note 40, at 106-11.

57. This is a major distinction from the general analysis of the Supreme Court, which heavily emphasizes the position of the median justice. In a liberal panel of three in which all panelists agree to a ruling that is consistent with the views of the most conservative member, or in a conservative panel of three in which all panelists agree to a ruling that is consistent with the views of the most liberal member, the preferences of those members, rather than of the median member, might be controlling if the objective is to create a precedent while reducing the likelihood of further appellate review. 
ences of the en banc court's median member, then the members can strategize as to how far they can depart from the median position while avoiding the likelihood of an en banc rehearing. This problem is generic in that it confronts all outlier three-judge panels on larger circuit courts.

The more interesting problem is identifying how, if at all, this calculation is affected by adopting the mini-en banc regime. In this regime, from the perspective of an outlier three-judge panel, there is considerably less certainty as to the full court's controlling median position because en banc review is effectively limited to the random draw of at least ten of the eleven judges. ${ }^{58}$ While it appears unlikely that the random draw would systematically generate either extreme wing of the court, at a minimum, there exists the possibility of a broadening of the effective median..$^{59}$ If we assume the ability to rank all twenty-eight judges along a single liberal to conservative dimension, then the true median would sit at positions fourteen and fifteen. In the mini-en banc, in contrast, the median range potentially expands from position six on the left to position twenty-two on the right. And even if we assume that most of the mini-en banc medians are closer to the true full-court median, the net effect of the regime change is still to broaden the effective median to a considerable extent. The result is to remove substantial restraint from outlier panels that inevitably emerge through a process of random drawing by providing those panels a broader cushion of acceptability - or a lower probability of overruling - relative to a traditional en banc regime.

A similar set of incentives confronts the mini-en banc itself. While the Ninth Circuit has never granted a full-en banc review of a mini-en banc decision, it is certainly possible that some day it will. And it is likewise possible that the mini-en banc panelists, with this in mind, strategically align their decisions closer to the median position on the Ninth Circuit as a whole than to the median position of the mini-en banc panel when there is a considerable issue space between the two. This of course raises an empirical question, but at a minimum, it suggests a possible countervailing force to the starkest predictions that assume a minority of six within the mini-en banc has free reign to bind the circuit. This tendency might be tempered by the very same incentives that an outlier panel has to reign in its decisionmaking sufficiently to reduce the risk of a further step of internal appellate review. ${ }^{60}$

58. See supra note 21.

59. A probability analysis of each potential median draw in a three-judge and eleven-judge panel is beyond the scope of this Review.

60. It is of course also possible that the circuit courts, or even the panels within those circuits, to some extent play a similar game in an effort to reduce the probability that the Supreme Court will grant the losing party's petition for certiorari. This incentive, however, confronts all circuits and not just the Ninth Circuit. 
While I have focused primarily in this Section on the role of the mini-en banc, the analysis suggests a more general point. In evaluating the Supreme Court, commentators are prone to imagining that the median jurist has near limitless power. ${ }^{61}$ This is not surprising given that as a general matter that Court hears all cases en banc. In theory, the circuit courts could empower their median justices in much the same manner. But to do so would require heightened use of en banc proceedings. To the extent that this assumption is relaxed when we are analyzing the federal circuit courts, either because the frequency of en banc review is low or because the circuits employ a procedure that allows a subset of the whole to review three-judge panel decisions, the effect is to broaden the effective median on circuit courts to a larger number of jurists. This affords panels considerably more flexibility within the circuit, at least if we assume as a primary goal the desire not to be overturned. The model might suggest that circuit courts are less predictable in turning preferences into doctrine than is the Supreme Court. And among the circuits, larger courts would appear less predictable than smaller courts. The Ninth Circuit in particular would appear to be even less predictable as a consequence of the mini-en banc procedure. While this analysis cannot resolve the policy debate over the wisdom of the mini-en banc, at a minimum it exposes an important cost that Cohen's interview data has not fully uncovered.

\section{CONCLUSION}

Along with Cohen, this Review has spent a disproportionate amount of time on the Ninth Circuit. My primary goal has been to show that students interested in appellate court decisionmaking need to appreciate the nature of the decisionmaking process within appellate courts, which is the focus of the Cohen study. But students also need to appreciate that appellate courts are constrained institutions, and that those constraints significantly affect the manner in which courts transform preferences into doctrine. There is much work to be done here, and this Review has barely scratched the surface. Cohen has written a valuable book - one that I recommend. The book reveals important synergies between and among sociology, economics, and statistics and probabilities in evaluating federal circuit courts. I hope that other academics, as well-steeped in these and related disciplines as Cohen is in his, will also take up the cause of applying the tools of their trade to these unique and important institutions.

61. See, e.g., Paul H. Edelman \& Jim Chen, The Most Dangerous Justice Rides Again: Revisiting the Power Pageant of the Justices, 86 MINN. L. REV. 131 (2001) (concluding that Justice Kennedy is "most dangerous"); Paul H. Edelman \& Jim Chen, The Most Dangerous Justice: The Supreme Court at the Bar of Mathematics, 70 S. CAL. L. REv. 63 (1996) (same). 


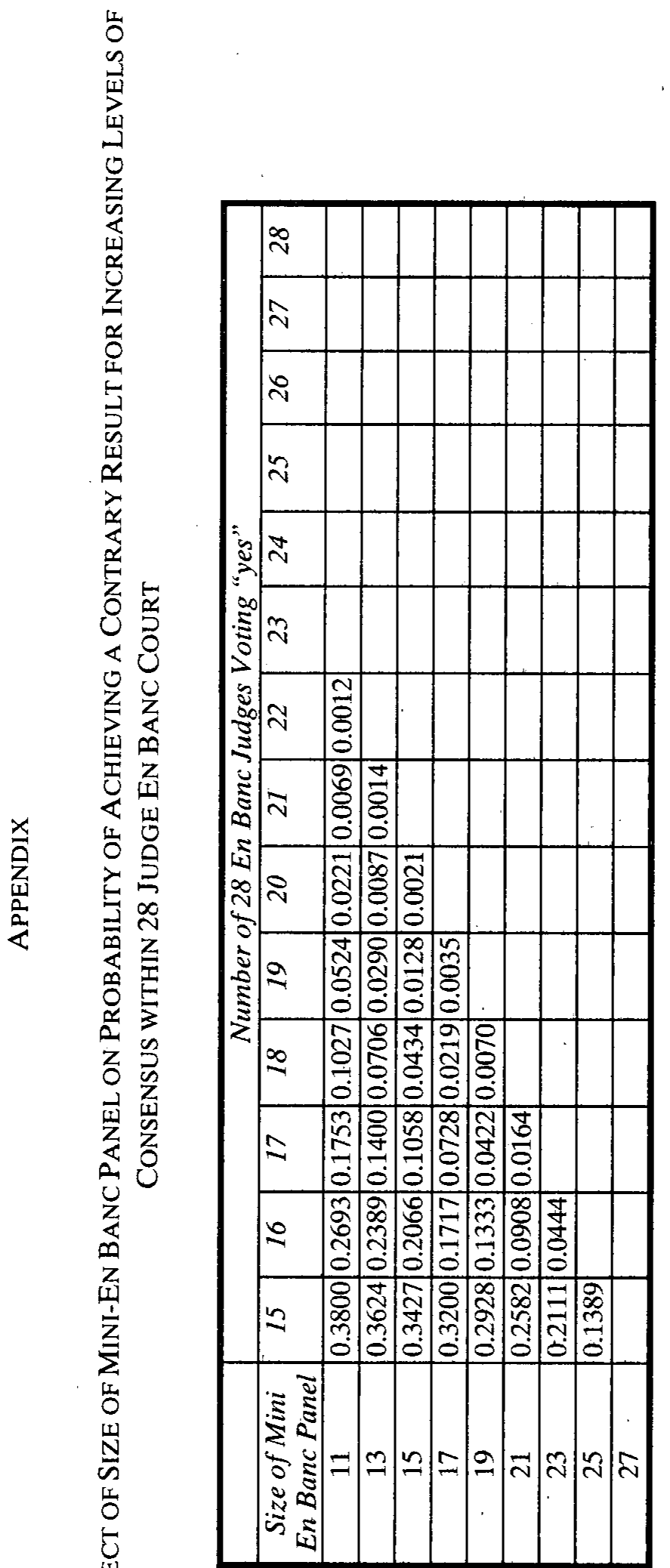

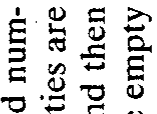

马्ठ를

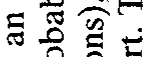

오옹융

过导

究的茴

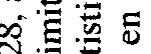

渮焉

홍응

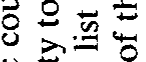

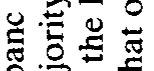

ง.ํํㅛ

ธี

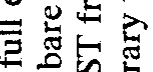

茫

घ용

0.

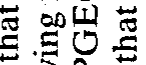

율

管

홍

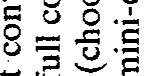

氖芯

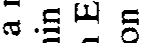

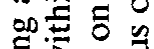

类证

路

势

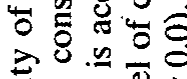

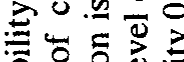

은

tho

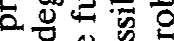

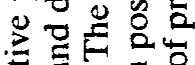

西完要

สิธัญ

可和声总

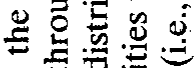

0

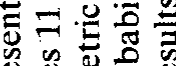

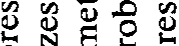

क्षे क्षे

额

$\cong \frac{0}{0}$

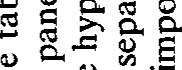

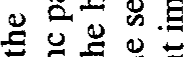

$\exists$ 政

ㄹ. 올.

है हो

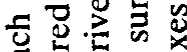

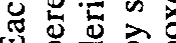




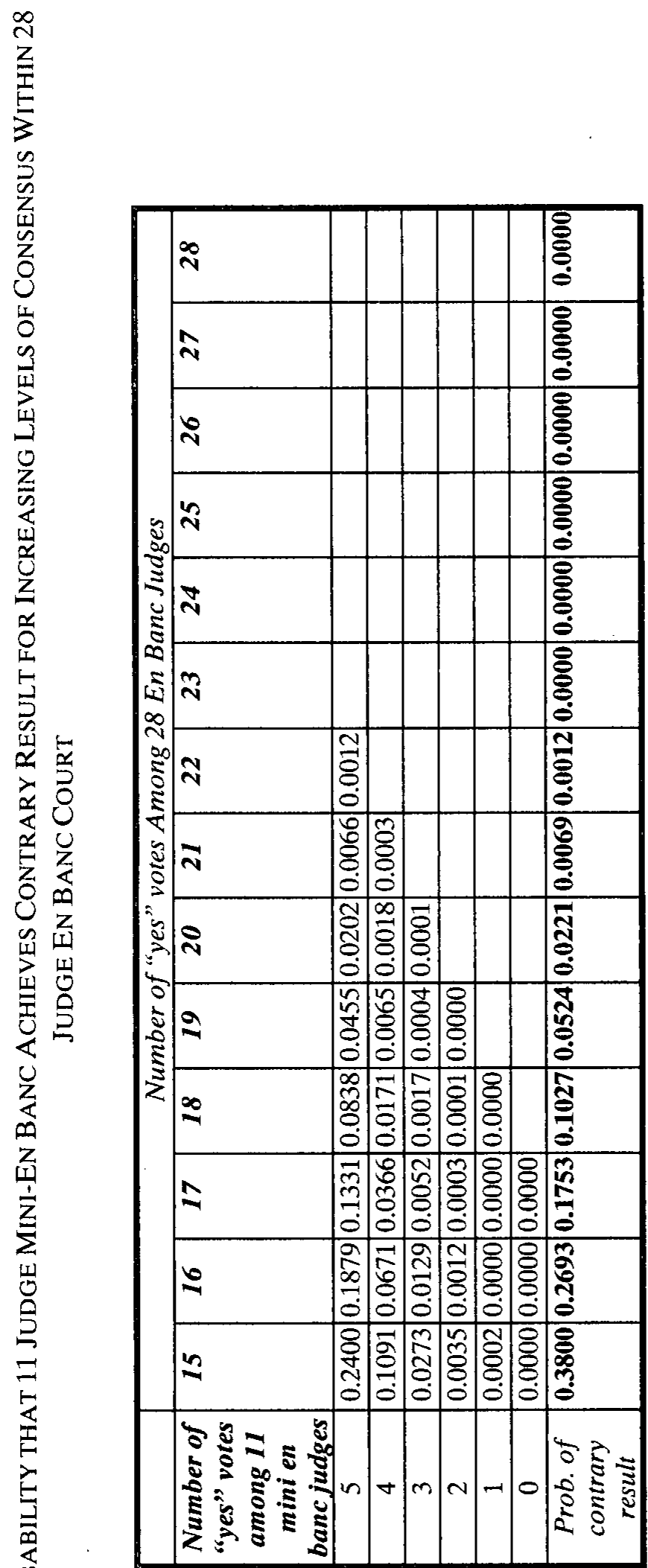

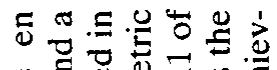

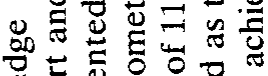

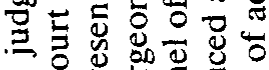

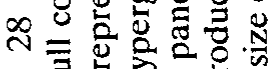
可

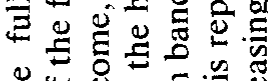
넝 능 을 要要

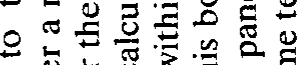

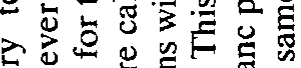

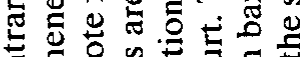
5

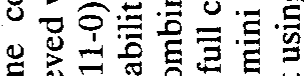

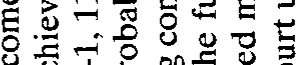

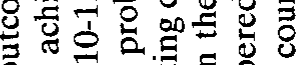
б.

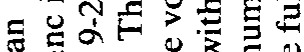

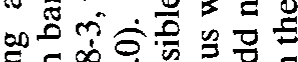
我品赂

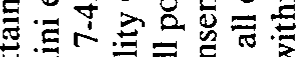

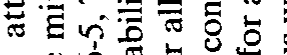
$=$ 二

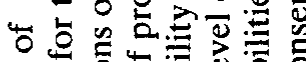
उ

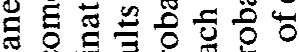

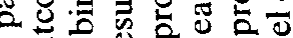

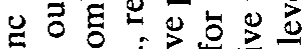

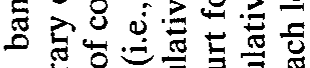
둔 \&

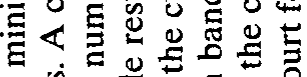
\% 论 石 ว동.

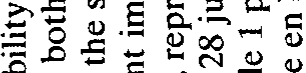

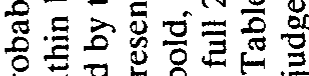

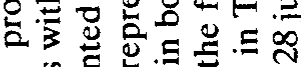

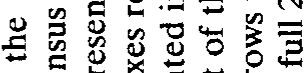

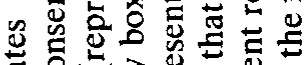

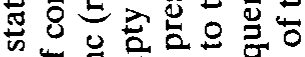

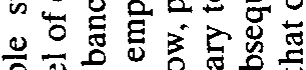
ए 0 ¿ 둥

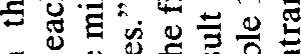
.

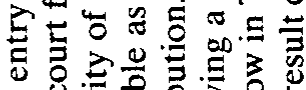

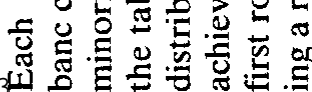

